\section{SOI: $1.1 /$ TAS DOI: $10.15863 / \mathrm{TAS}$ International Scientific Journal Theoretical \& Applied Science}

p-ISSN: 2308-4944 (print)

e-ISSN: 2409-0085 (online)

Year: 2015

Issue: 09

Volume: 29

Published: 30.09 .2015

http://T-Science.org

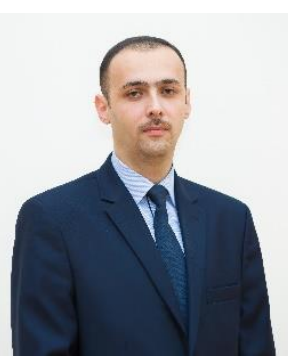

Elnur Latif oglu Hasanov

Corresponding member of

International Academy of

Theoretical and Applied Sciences,

Ph.D., Senior specialist of

Ganja Department

Azerbaijan National Academy of Sciences,

Ganja, Azerbaijan

1-hasan@hotmail.com

SECTION 12. Geology. Anthropology.

Archaeology.

\title{
ABOUT INVESTIGATION OF SOME INNOVATIVE FACTS ON THE HISTORICAL PAST OF GANJA CITY
}

Abstract: In this scientific work were systematic researched the main features of historical development of Ganja city as an important Urban civilization center. Some problems of innovative research of ethnographic and historical characteristics of this city have been also investigated on the basis of different scientific sources.

Key words: Ganja, Urban civilization, innovative research methods, historic-ethnographic research, historical past, Azerbaijan.

Language: English

Citation: Hasanov EL (2015) ABOUT INVESTIGATION OF SOME INNOVATIVE FACTS ON THE HISTORICAL PAST OF GANJA CITY. ISJ Theoretical \& Applied Science 09 (29): 7-11.

Soi: http://s-o-i.org/1.1/TAS-09-29-2 Doi: crossef http://dx.doi.org/10.15863/TAS.2015.09.29.2

There is a fierce gun, it is not gold. Ganja still strongly sticks on my collar, In other case I would seized Iraq's treasures.

A voice came from the World:

- O slave, that's enough fun!

Who is Nizami, and where is Ganja.

Sheikh Nizami Ganjavi

\section{Introduction}

In one of the ancient Zoroastrian's sources there was important information about that Ganja was founded three-four thousand years ago. Thus, the first and important information about, that Ganja was founded 4000 years ago by the one of the ancient Turkish tribes - Sacks - one of aboriginal population of the Caucasus, was reflected in a geographical treatise "Shahrestani Eran" (Iranian cities) that concerned to the 6th century. This geographical treatise was written in Pahlavi language. There was said, that Ganja was founded by famous Turkish commander Afrasiab 4000 years ago. Afrasiab is a historical person and he was the head of sacks-tours, which lived in Azerbaijan (In the ancient sources Turks were named as tours).

Ganjabasar is one of the richest areas from archaeological point of view. As a result of archaeological investigations here were found samples of material culture that concerned to the stages of different history period. Today most of them are kept in various museums of the world.
The flint tools, that found in Gillikdag workshop and camp around Ganja, ladle, that were found by a prominent Azerbaijani archaeologist Isag Jafarzade, give the reason to say, that people, who lived in this area in VII - VI millennium BC were the founders of the Late Stone Age culture.

Archaeological investigations prove that in this period the main population of this region had sedentary lifestyle and were engaged with farming. In $\mathrm{V}$ millennium $\mathrm{BC}$ in Ganja region all known to us domestic animals were domesticated. This fact is approved with osteology remainders that were found during archaeological excavations.

The anonymous author of the article "Russian city" gave the schedule indicating the date of cities of the South Caucasus, also of Azerbaijan. And here he matched, that Ganja was founded in II century BC.

The same words, that match, that Ganja is older than Barda and Beylagan prove Qagemeyster's information and conception, that says "At a short distance from Barda another city was also flowering, which at the time of destruction 
substituted it. It was Ganja city. Their origin, probably, was the same...".

The biology teacher of the secondary school of Yelenendorf (Goy gol) Yakov Hummel, who has German nationality, with the power of students circle of the school carried out archaeological research works on the right and left banks of Ganjachay, in the Gillikdag area near Goy Gol, in Zurnabad, Balchilı and has gained valuable materials of Bronze Age and Early Iron ages. The value of found materials was so great, that with their account has been created Yelenendorf Museum of Country Studies in 1927.

\section{Materials and methods}

Most of the historical monuments, that show, that national wealth of our nation Ganja city has a 4000-year history, today in great museums expositions of the world have unique place. In Metropol (USA) Munich, Berlin, Hamburg, Louvre, Paris, Moscow, St. Petersburg and other cities in the state and private museums rare and valuable exhibits of the history of ancient Ganja are preserved.

Ganja, that has changed its location at least 4 times since its establishment, is located in a favorable position from the strategic point of view. That why it always has been the center of attention of foreigners. Ganja, that was the victim of a terrible earthquake many times, also was the subject of attacks of Mongols, Kharezms, Georgians, Arabs, Russians and other invaders. Ganja has turned to the arena of war damage of different countries of the world. But in spite of it didn't shaken, and using the genetic power revived and developed, and rose to the level of great cities.

The famous Arabian historian and geographical scientist Ibn al-Athir valued Ganja as the hero-city and said: "Tatars (Mongols) after robbing and ruining Beylagani and it's around moved to Ganja. But when Tatars knew, that its population is big, they have shown bravery in the war with Georgians and the strength of this city, they couldn't go there".

Protecting the status of capital city Ganja, in the various stages of the history, had an important role in the preservation of the ancient statehood traditions of Azerbaijan. At the end of the VII century Ganja was the provincial city of Arabs, in the $\mathrm{X}$ century the capital of Arran, in the XI century Seljuk's, in the XII-XIII centuries was the residences of Atabek's empire. During this period Ganja had renaissance time of its development, science, culture, trade, crafts reached the highest peak.

As a result of scientific researches by the wellknown arabist and scientist on Nizami's work Bertels have proved, that during the terrible earthquake in Ganja in 1139, 300 thousand people died. This fact is reflecting the city's power and greatness again. For comparison, it is also appropriate to note that, in the middle of the XIII century, in the great European city in Paris, lived nearly 100 thousand and in London nearly 40-50 thousand people.

Ganja city, that gave to the world such great thinkers and word masters as Nizami Ganjavi, AbulUla Ganjavi, Mahsati Ganjavi, Raziyya Ganjavi in XII-XIII centuries restarted its high status and became one of the great cities, that kept alive the whole science, culture and state traditional system of the East.

Sheikh Nizami also has got both of the primary and secondary, and scientific education in his favorite city in Ganja. He had two main reasons, why he didn't go to Baghdad and other centers of science. He loved his native city, land, was charmed of it, and also he knew, that Ganja had the high scientific potential. So the great thinker has never left his homeland and thought about it.

In other words, if the poet would have the power to leave his native city, he moved to the center of Caliphate to Bagdad, and collected great treasures with unexampled art. For this reason, great memoirist of Middle Ages, who saw beside "Khamsa", "Divan" with 20 thousand stanzas Douletshah Samargandi stated "an honorable place of birth Sheikh Nizami is Ganja". Don't forget that, genius as Nizami can't be unfounded. For appearing they need historical with ancient traditions, socio-economic and cultural environment. The existence of such environment again proves that Ganja has 3 thousand year history. Because for turning one city to the scientific and cultural center it needs an ancient tradition and a long period of time.

During XV century Ganja was included to the states Garagoyunlu and Aghgoyunlu and managed by different rulers. During the rule of Uzun Hasan Agqoyunlu Ganja's trade relations with other cities were widen and it has resulted its re-development.

By the opinion of research scientist M.X.Heydarov, in this century one of the great tradecraft centers of Azerbaijan was Tabriz, Ardabil and Khoy and also Ganja. In Ganja appeared craftsmanship organizations that based on ideology "Akhilik" and the most important professional form of organization - Trades unions were active.

During Safavid's ruling Ganja was one of the important cities of Azerbaijan and the whole East. Ganja -Karabakh's beylerbeylik was one of the big provinces of Safavid State on territory.

Province's broads were continuing along the Kura River on the north to the west from the place, where Kura River connected with the river Araz, to Bargushad pin (the province are considered) in Irevan and on north direction passing through the eastern part of the lake Goycha again to the north, entered to the Tiflis province, and rose up to the province of Lori.

At the beginning of the XVIII century, Ganja City has retained the status of largest and most important city. At the end of XVII century - at the 
beginning of the XVIII century, a number of travelers, who visited Azerbaijan, have given wide information about its size and beauty.

Netherlands traveler Kornelia de Bryu wrote about Ganja so: "Ganja is located on 50 lye distance from Shamakhy, it is bigger than Shamakhy for four times, there are stone buildings there, most of them are two floors, it has beautiful and great karvansarays, deputy has large and wide palace there. The beautiful river flows on the city's territory, there are many gardens, good wine and plenty of fruit here. So, this city of can be considered as one of the most important cities of the East. This information was given to me by the French missioner and several Georgians that lived in this city".

\section{Conclusion and Recommendations}

However, the political problems and foreign military intervention to Azerbaijan in the first half of the XVIII century made a lot of Azerbaijani cities, also Ganja city suffered and was the reason of its destroying and completely turning to ruins.

This situation did not continue for a long time. In 1747 after Nadir Shah's killing palace's aristocrats a result of conspiracy, his empire collapsed. Many small government entities on the territory of Azerbaijan - khanates appeared. One of these khanates was Ganja Khanate that appeared around Ganja city.

New danger on Ganja was activation of the policy of Russia in the South Caucasus.

After successful military operations against Osman's Turkey and its close ally - the Crimean khanate in order to enhance their success in the South Caucasus Russian government prepared an action plan.

One of the Javad Khan's contemporaries S.S. Kovalesky in 1880 in notes about Georgia gave such kind of opinion: "Javad Khan from the Qajars family in 50 years old with his intelligent and policy and also good negotiation who found a good reputation".

In November of 1803 year Ganja was attacked with the Russian forces. In the first weeks of attack strong resistance of the city's defenders made Russians maneuver, made them replaced often marches with long-term siege. Russian troops by blockading city, keeping people without water and food wanted to make people surrender. For this reason, Tsitsianov kept the city in blockade without water and food untill epidemic was spreading. In spite of all difficulties Ganja people preferred statehood and independence above all by values and didn't surrender to enemy.

As a result, the living force of Russian troops and war supplies were better, and military operations have been resolved in their favor. Ganja's occupation among the defenders, and also the population led to massive losses. According to Tsitsianov's information on the 8th of January 1804 year, among the defenders 1,500 people were killed, 17224 male and female were prisoners of war.

On the 8th of March 1804 year, in the letter to Tsar Tsitsianov asked to change Ganja's name: "If Your Excellency like my proposal, I would like to dress up city's name with the Holy name of Her Excellency empress Elizabeth Alekseevna: Yelisavetpol".

Tsitsianov, who got Emperor Agreement, as signed such kind of direction: "After 1 month of declared of Tsar's prescript after or from April 1, if someone in acts matches Ganja with the old name not as Yelisavetpol, it will be a penalty in the amount of ruble."

After the restoration of independence of Azerbaijan Republic, Javad Khan became a symbol of our courage, patriotism and bravery.

Worthy successor of the great leader Heydar Aliyev's political course President Ilham Aliyev said: "I know that Ganja peoplehold the memory of Javad Khan daringly. Really he is one of the notable sons of Azerbaijan people, is an example of perseverance and courage. His grave in the center of the city is not in accordance with his memory. I think that we should raise a mausoleum. The city will take a new form of architecture, and also Javad Khan's memory will worthy become eternal".

Exactly as a result of the attention and care of country Head with the support of Heydar Aliyev's Foundation in 2005 in Ganja was built a worthy mausoleum for Javad Khan. Historical emblem of Ganja Khanate was restored; film about Javad Khan was released.

At the end of the XIX century, in connection with the emergence of the capitalistic relations, one of the cities of Azerbaijan, where were the processes of formation of its main classes, bourgeoisie and proletariat was Ganja. The development of capitalistic relations in the different fields of city economy, its attraction to all-Russian market speeded this process.

"Turkish Revolution Committee of socialfederalists", that showed the exceptional services in the establishment of the Azerbaijan Democratic Republic in 1905 and creation "Difai" Party in Ganja, that was founded in order to protect our nation from the Armenian terrorism, once again showed, that Ganja people could bate all their creatures for traditions, statehood and independence.

Thanks to the representatives of the national bourgeoisie patriots, formed in Ganja, under the leadership of Nuru Pasha was created the Caucasus Islamic Army that saved Azerbaijan from the Armenian and Bolshevik forces ruthless genocide and created an incentive of the future of our country. For this reason, the capital of Azerbaijan Democratic Republic, that declared its independent in May, 28 in 1918, became Ganja. The leaderships of our first national state were outstanding and public men and 
statesmen, who have belonged to the noble family of Ganja.

On April 27, in 1920, after Azerbaijan Democratic Republic's overthrown by the Bolsheviks that supported by bloody actions of XI Army, just only Ganja for the first time raised its statehood independence and freedom voice against the Soviets. The arbitrariness of occupying army, shooting of innocent people, made Ganja people to begin Ganja rebellion against foreigners in a glorious page of history.

Brother of Great Uzeyir Bey Jeyhun Hajibeyli said about Ganja uprising full and exact thoughts:"Ganja's uprising is a story that again earned nation's honor. In May Turkish blood wiped spot, that the road to our nation during events on 27 April. Thus, Ganja began its soviet period of its history with revolt. "

According to decision on July 30, in 1918, Ganja's name, that was called Yelizavetpol Province, returned to itself, but in 1935 with the instruction of Moscow Ganja's name changed again into Kirovabad. Thus, Ganja got name of S.M.Kirov, who played an important role in establishment the colonial regime, and Autonomous Oblast for armenians in our land.

Since 1969, under the leadership of national leader Heydar Aliyev there were regarded the works to return Ganja's historical face. First of all, the historical monuments of the city that have fallen into a bad situation, (especially mosques) were restored. However, the main issue of concern for the national leader Heydar Aliyev, was the return of the city's historic name. At that time, this ancient city was given the name of S.M.Kirov, who was the favorite of communists of Russians. It was not easy to retrieve was the previous name of city. Despite these challenges, one of the major persons was thrower by national leader Heydar Aliyev in 1980. Thus, in the same period in Kirovabad was created two new district and one of them was given the name Ganja. Also, the new housing area, that was built here, was called "New Ganja".

In that years, there were established such kind of great cultural objects as the poetry theater, named after Nizami, Art Exhibition Hall, Children's Art Gallery, Children's Sports Games Complex, "Sherefkhanli country song's theater", "Abulfaz Nakhchivani", "Xezine" ("Treasure"), "Nizami Ganjavi-Pushkin" libraries, Ganja State Philharmonic, Chamber Orchestra, "Nizami Ganjavi's house museum". In general, the number of such kind objects, that were created in Ganja in 1969-1982, was more than 40.

After the collapse of the Soviet Empire, our motherland Azerbaijan was testing on hard and difficult fate, the economic, social and political tensions created the fear of losing of country independence. In such difficult circumstances, thanks to the management capacity and fine political feeling of national government prevented civil war in the western region and protecting Azerbaijan's independence. So in Azerbaijan began a new development stage.

\section{References:}

1. Abdullaeva NA (1971) Kovrovoe iskusstvo Azerbaydzhana. Baku: Elm.

2. Agamalieva SM (1987) Goncharstvo Azerbaydzhana. Baku: Elm.

3. Azerbaydzhantsy (istoriko-etnograficheskiy ocherk) (1998) Baku: Izd-vo Elm.

4. Bünyadov TӘ (1977) Azərbaycan atçılığın tarixindən // AEM, 3-cü buraxılış.Bakı: Elm.

5. Bünyadova ŞT (1992) Nizami və etnoqrafiya. Bakı: Elm.

6. Voennyy sbornik (1912) t. Kh, pp. 328-331.

7. Cavadov QC (1977) Azərbaycanda ağacişləmə sənəti haqqında. AEM. III buraxılış.

8. Çəmənzəminli Y (1927) Azərbaycanda zərdüşt adətləri. Maarif və mədəniyyət, № 4-5.

9. Ofəndiyev RS (1966) Azərbaycanın bədii sənətkarlığı. Bakı: Azərnəşr.

10. Ofəndiyev RS (1976) Azərbaycanın dekorativtətbiqi sənətləri. Bakı: İşıq.

11. Ohmədov FM (2007) Gəncənin tarix yaddaş1. Gəncə: Elm.
12. Gasanov EL (2014) O razvitii traditsionnykh remeslennykh otrasley Gyandzhi na rubezhe XIX-XX vekov. Fundamental'nye issledovaniya. № 9-4. pp. 892-895.

13. Gasanov EL (2014) Traditsionnye etnoantropologicheskie i istoricheskie osobennosti osnovnykh remeslennykh otrasley Gyandzhi XIX - nachala XX v. Vestnik Leningradskogo gosudarstvennogo universiteta im. A.S. Pushkina. T. 4. № 3. pp. 86-90.

14. Gəncənin məhəllə adları (1978) Elm və həyat jurnal1, №10.

15. Guliyeva NM, Häsänov EL (2014) Die traditionelle Gändschänischen Teppiche von Zeitraum der Aserbaidschanischen Gelehrten und Dichter Mirsä Schäfi Waseh als ethnoanthropologische quelle (XIX Jahrhundert). European Applied Sciences, 2, pp. 3-5.

16. Hasanov EL (2014) Innovative basis of research of local handicraft branches of Ganja of the 


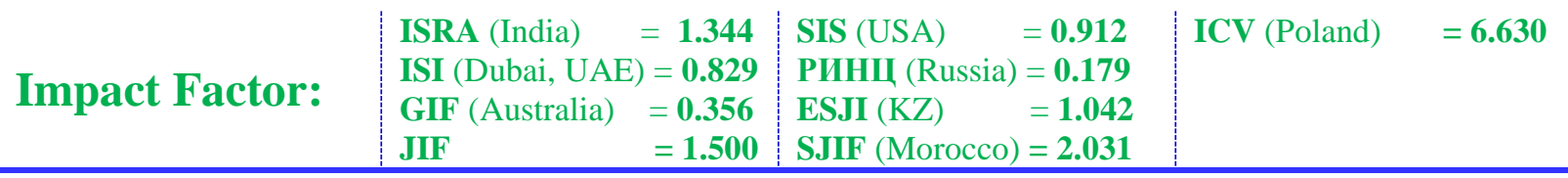

second half of XIX - beginning of XX centuries. Mediterranean Journal of Social Sciences, vol. 5, № 23, Part IV, pp. 2359-2362. Doi:10.5901/mjss.2014.v5n23p2359

17. Hasanov EL (2014) To the question on the research of typical features of craftsmanship heritage of Ganja of the late XIX - early XX centuries. ISJ Theoretical \& Applied Science 12(20): 27-30. doi: http://dx.doi.org/10.15863/TAS.2014.12.20.7

18. Hasanov EL (2014) Basic craftsmanship branches of Ganja of the second half of XIX beginning of $\mathrm{XX}$ centuries as a historicethnographical source. 社会科学と人文科学のアジアジャーナル. 大山、日本. (Asian Journal of Social Sciences \& Humanities), vol. 3, Number 3, pp. 9-14.

19. Hasanov EL (2015) Multidisciplinary approach to investigation of the basic handicraft branches of Ganja till the XX century. ISJ Theoretical \& Applied Science 1(21): 7-15. DOI: http://dx.doi.org/10.15863/TAS.2015.01.21.2

20. Hasanov EL (2015) To the Question on Research of Craftsmanship Traditions of Ganja of XIX - First Half of XX Centuries. Mediterranean Journal of Social Sciences, vol. 6, № 1, Part S1, pp. 433-437. Doi:10.5901/mjss.2015.v6n1s1p433

21. Həmidova İ (2000) Azərbaycan parça sənətinin tarixi inkişaf yolları. Elmi axtarışlar, VIII toplu, Bak1.

22. Həvilov HA (1991) Azərbaycan etnoqrafiyas1. Bak1: Elm

23. Kitabi-Dədə Qorqud (1978) Bak1: Gənclik.
24. Qasımov M, Quliyev H (1986) Qədim xalq boyama üsulları. Qobustan, № 1 (69), Bakı.

25. Məmmədov FN (1976) XIX əsrdə Gəncə şəhərinin ərazisi, əhalisi və idarəsi (1868-ci ilə qədər). Azərbaycan SSR Elmlər Akademiyasının Xəbərləri (Tarix, fəlsəfə və hüquq seriyas1), №3, pp. 30-37.

26. Məmmədzadə K (1978) Azərbaycanda inşaat. Bakı: Elm.

27. Mustafayev A (2001) Azərbaycanda sənətkarlıq. Bakı: Altay.

28. Nishiaki Y, Hasanov EL (2014) About ethnoarchaeological and anthropological research of some prehistoric monuments of Ganja. ISJ Theoretical \& Applied Science, 1: 45-48.

doi: http://dx.doi.org/10.15863/TAS.2014.01.9.8

29. Obozrenie Rossiyskikh vladeniy za Kavkazom (1836) ch. II, SPb, 1836.

30. Obozrenie Rossiyskikh vladeniy za Kavkazom (1837) SPb, 1837.

31. Obozrenie Rossiyskikh vladeniy za Kavkazom (1836) t. I, SPb, 1836.

32. Obozrenie Rossiyskikh vladeniy za Kavkazom (1836) t. II, SPb, 1836, pp. 234.

33. Smith WB, Hasanov EL (2013) Importance of handicraft traditions in investigation of history of urban culture in Ganja. ISJ Theoretical \& Applied Science 11(7): 61-66. doi: http://dx.doi.org/10.15863/TAS.2013.11.7.10

34. Tərlanov M, Ofəndiyev R (1960) Azərbaycan xalq sənəti. Bakı: Uşaq gənc nəşr.

35. The dawn of Art (1974) Leningrad: Aurora Art Publishers. 